\title{
Trade as an Option for Managing the Impacts of Supply Risks in Coconut Production: Importation of Dehusked Coconuts, Copra and Kernel
}

\author{
P.M.E.K. Pathiraja ${ }^{1}$, G.R. Griffith ${ }^{2}$, R.J. Farquharson ${ }^{2}$, R. Faggian ${ }^{3}$, \\ I.M.S.K. Idirisinghe ${ }^{1}$, M.G.D. Abeysekara ${ }^{1}$ and S.D.J.N. Subasinghe ${ }^{1}$
}

\begin{abstract}
The Sri Lankan coconut industry is facing intense competition due to increasing demand from local consumption and export processing while fresh nut production is stagnating. The situation is aggravated during weather extremes especially with prolonged droughts. The recent prolonged drought of nearly two years was the cause for temporary closure of processing industries and soaring nut prices. It may take more than a year to re-establish normal yield even with the onset of rainfall in October. Therefore, importation of coconuts as a strategy was explored in this study. An Equilibrium Displacement Model (EDM) was used to quantify the possible economic impact and its distribution among industry stakeholders. The results indicated that allowing imports is economically viable for the processing industries to recover their losses. Under the simulated scenarios where input substitution is a policy condition to be zero, reducing the costs of processing of desiccated coconut through fresh nut importation reduces the losses to the processors and exporters from 15.5 LKR million per year to about 5.5 LKR million per year. Consumers of desiccated coconut exports are also better off by around 45 LKR million under the above scenario of a price reduction of fresh nuts from 43 LKR to 32 LKR. However, still there are concerns for the existence of markets produced from foreign material and export substitution. Moreover, the compliance with the quarantine regulations especially for the risk of pest and disease outbreaks remains unresolved. Therefore, dehusked-coconut importation is still not an option for a severe coconut shortage while other semi-processed products may remain potential alternatives.
\end{abstract}

Keywords: Fresh nut production, Prolonged droughts, Equilibrium Displacement Model (EDM), Importation, Export substitution

\footnotetext{
${ }^{1}$ Coconut Research Institute, Lunuwila, Sri Lanka.

${ }^{2}$ University of Melbourne, Parkville, Australia.

${ }^{3}$ Deakin University, Burwood, Australia.
} 


\section{Introduction}

Coconut is a rain-fed perennial crop cultivated in nearly 20 per cent of the arable lands in Sri Lanka. Currently, the industry is facing intense competition due to increasing demand from local consumption and export processing while fresh nut production is stagnating and fluctuating with the climatic uncertainties. The coconut industry has experienced a prolonged drought over the past two years, and according to the predicted yield for 2017 , it is nearly a 17.5 per cent reduction from that of previous year. This is about equal to the yield in 2010; however, currently the export demand is comparatively high with respect to the situation in 2010. Therefore, the demand for fresh nuts is comparatively high, and there is a significant shortage in the market of around 250 million to 650 million nuts for the processing industries (both local and export processing).

This shortage is expected to recover only with the favourable weather. Even with the onset of rainfall, the impact on yield would exist over 9 to 13 months and even beyond. There is also an irreversible impact due to death of palms which is not calculated. During a severe coconut shortage, banning fresh nut exports and reducing the tariff on edible oil imports are practiced to increase the availability of fresh coconuts and to stabilize the fresh coconut prices. However, during the present yield drop, these measures were not effective especially due to the increasing demand for export processing and a reduction in nut size owing to the prolonged drought. The possibility of supplementing culinary nut usage with imports of coconut milk powder and coconut paste is an alternative to save nuts for the industry. However, shifting the consumption pattern is unrealistic to a certain extent. Since the recurrence of such climate extremes cannot be ignored in future, it is worthwhile to consider the possibility of importation of de-husked nuts, kernel or copra as an alternative to cater for the industry demand for coconuts.

Therefore, this study aims to identify the context of the industry, to quantify the economic impact of a possible nut shortage to the industry and the industry stakeholders, to identify the possible economic gain to the industry processors from de-husked coconut importation and to identify what other factors to be considered in importation of de-husked coconuts.

\section{Role of Coconut Sector in the Economy}

\section{Contribution to the Economy}

The coconut industry plays an important role in sustaining the national economy of Sri Lanka and the food security of the people. It contributes around 0.7 per cent to Gross Domestic Product (GDP), 12 per cent to export earnings from agriculture, and 3.3 per cent to total export earnings (Central Bank of Sri Lanka, 2016). The per capita culinary consumption of coconut is around 84 coconuts per year per person excluding coconut oil consumption (Department of Census and Statistics, 
2016). Adding in coconut oil consumption, total household consumption accounts for 65 to 70 per cent of the total coconut production of the country, which is around 3,000 million nuts per year (Table 1). Coconut is the major source of edible oils and fats in Sri Lankans' daily diet providing about 12 per cent calorie intake of an average person (FAO, 2013).

Export earnings of the coconut sector have exceeded 84,701 LKR million LKR in 2016 (Coconut Development Authority, 2016). These export products of coconut can be broadly categorized as kernel products, fibre products, shell products, finished products (fibre) and other miscellaneous products such as coconut ekels, coconut wood and fatty acid. In addition, the processing industries together with the cultivation sector provide employment for nearly 500,000 people. Coconut cultivation is a source of income for nearly 700,000 land holders in the county (Ministry of Plantation Industries, 2007).

\section{Current Production Levels and Industry Potentials}

During the past few years, domestic consumption and domestic processors had the potential of absorbing the total coconut production in the country. Nearly two thirds of the coconut production (70 per cent) had been used in culinary purposes and the balance was exported as processed products and fresh nuts (Table 1).

Table 1: Nut utilization pattern 2013-2016 November

\begin{tabular}{lrrrr}
\hline Product & \multicolumn{4}{c}{ Nuts (million) } \\
\cline { 2 - 5 } & 2013 & 2014 & 2015 & 2016 \\
\hline Coconut Oil (Export) & 14.95 & 34.55 & 75.42 & 56.30 \\
Virgin Coconut Oil (VCO) & 25.21 & 87.34 & 160.23 & 168.73 \\
Desiccated Coconut (DC) & 219.89 & 398.68 & 281.71 & 356.00 \\
Copra & 0.37 & 24.98 & 2.56 & 5.13 \\
Fresh Nuts & 21.46 & 33.07 & 13.20 & 28.37 \\
Coconut Cream & 12.41 & 14.99 & 22.41 & 26.48 \\
Coconut Milk & 40.85 & 50.35 & 71.36 & 93.25 \\
Coconut Milk Powder & 65.83 & 81.69 & 78.99 & 87.18 \\
Local coconut oil production & 392.86 & 393.38 & 458.75 & 390.82 \\
Total nut utilization for & 793.82 & $1,119.02$ & $1,164.63$ & $1,212.27$ \\
processing & & & & \\
Nut requirement for & 1,827 & 1,827 & 1,827 & 1,827 \\
consumption & & & & \\
Total nut utilization & $2,620.82$ & $2,946.02$ & $2,991.63$ & $3,039.27$ \\
\hline SolCo & & & & \\
\hline
\end{tabular}

Source: Coconut Development Authority, 2012, 2017 
The industry demand has shown an increasing trend with the emerging demand for virgin coconut oil, coconut milk and coconut milk powder (Figure 1). According to the figures of last five years, domestic culinary requirement is around 1,800 million (Table 1). The remainder goes for the processing industry. In recent years around 1,200 million nuts are required for processing industries. As depicted by Figure 1, fresh nut requirement for export processing has been increasing over the years. The bars show the average demand for export processing during 2012 to 2016.

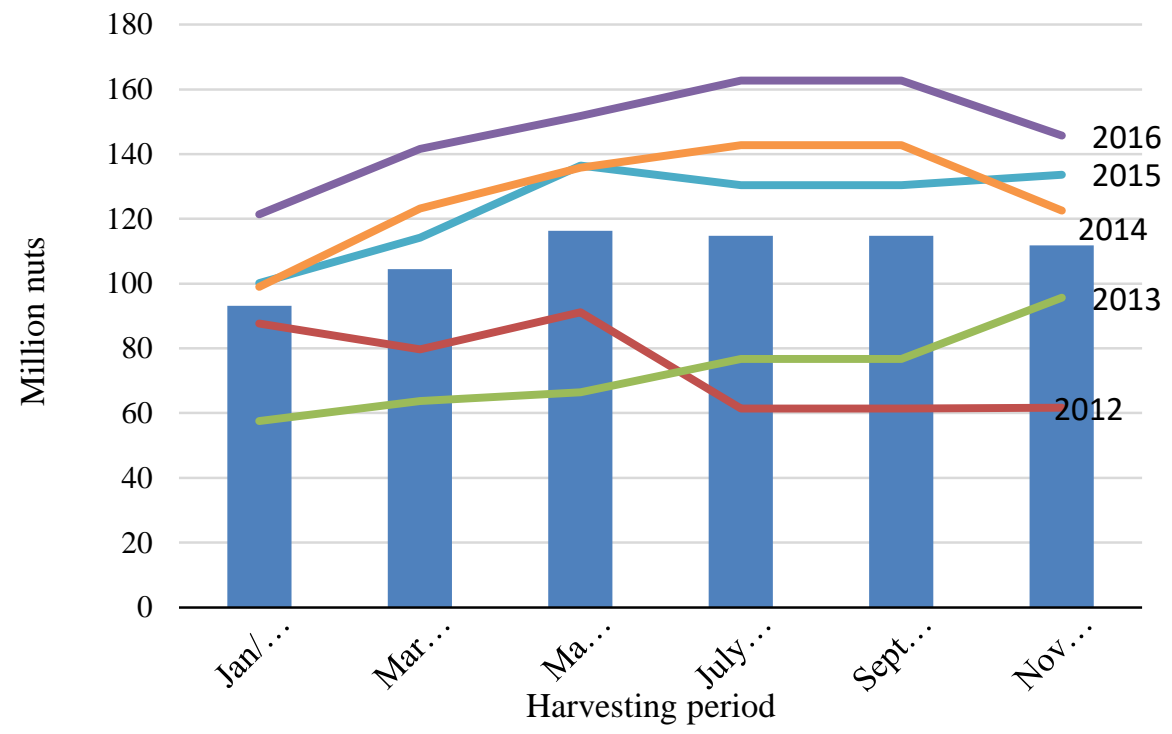

Figure 1: Export requirement over last five years

Source: Coconut Development Authority, 2012, 2017.

Similar to most other agricultural products, coconut has a seasonal pattern of production, which generally changes depending on the distributed rainfall pattern. Previous research has shown that nearly 60 per cent of the yield is climate determined (Fernando et al., 2007). Coconut production shows yearly variation (Figure 2) as well as within year variation (Figure 3). Actual production in 2016 and the forecasted yield for 2017 are shown in Figure 4. Accordingly, depending on the supply levels and the demand for nuts, price variations can be observed in the coconut sector. Similarly, there are influential factors on the price level of coconut in the market which indirectly manipulate the fresh nut demand. Price of substitute edible oil in the world market, health benefits quandary on coconut oil, import tariff levels and world market price for desiccated coconut are among those. 


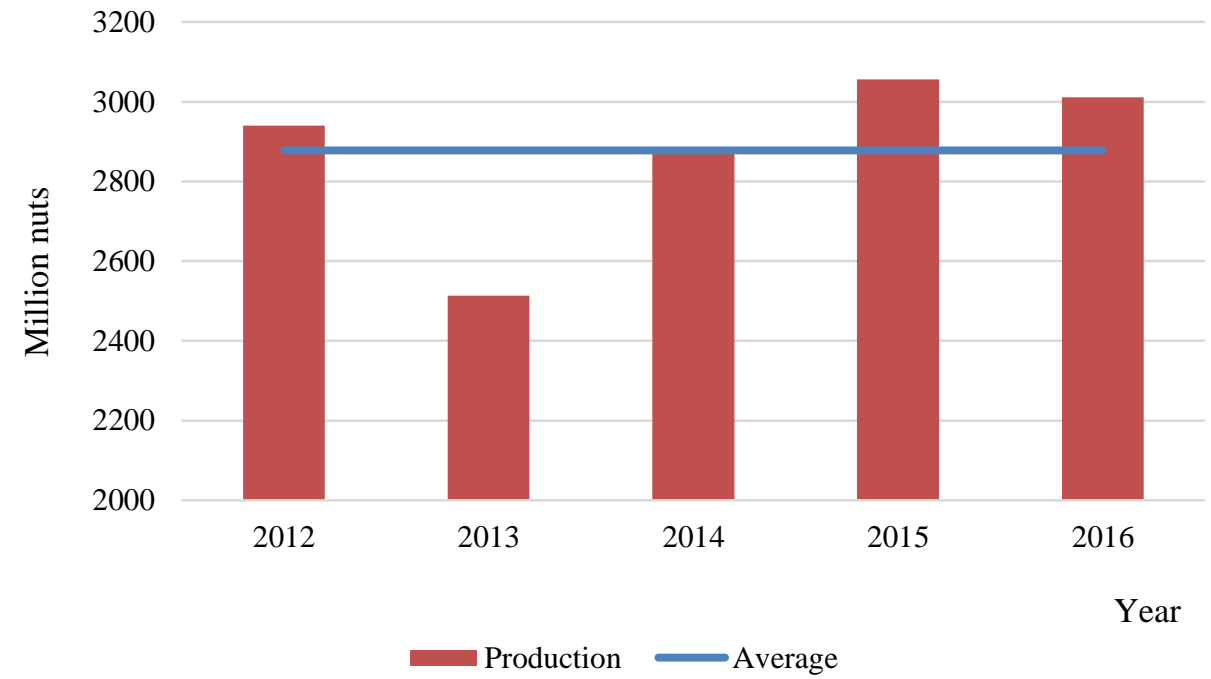

Figure 2: Coconut production over last 5 years

Source: Coconut Development Authority, 2012, 2017.

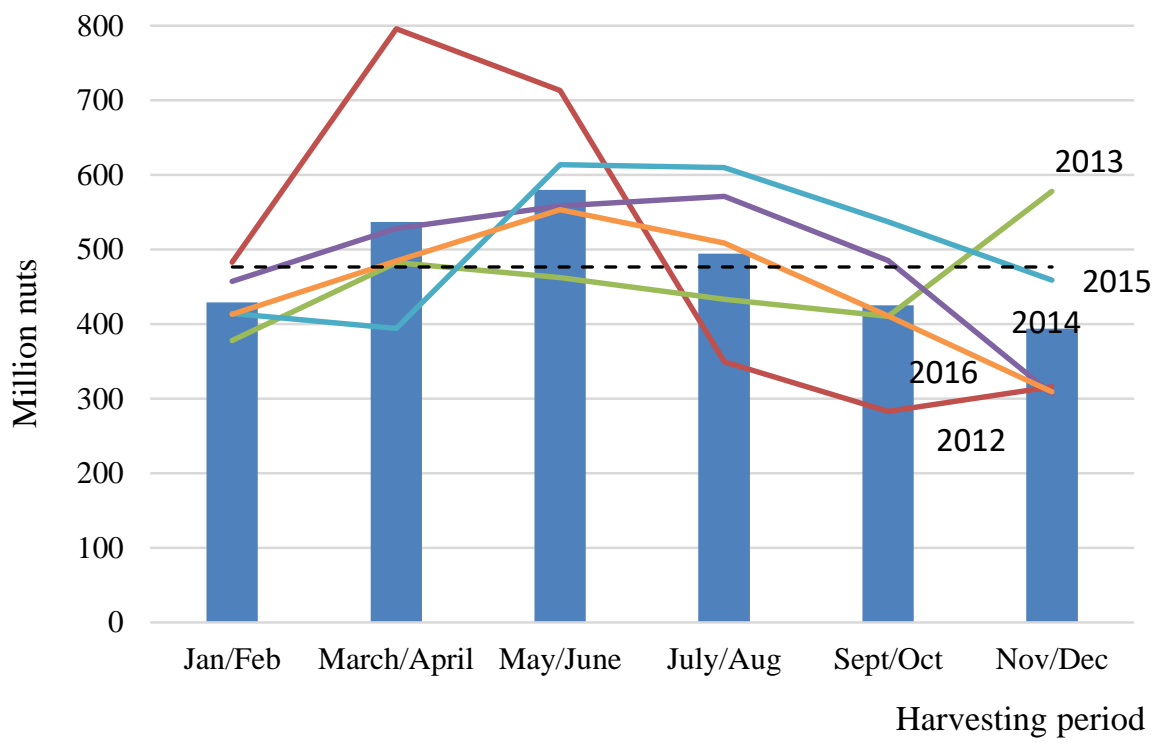

Figure 3: Piece-wise yield fluctuation over last five years

Source: Coconut Development Authority, 2012, 2017. 


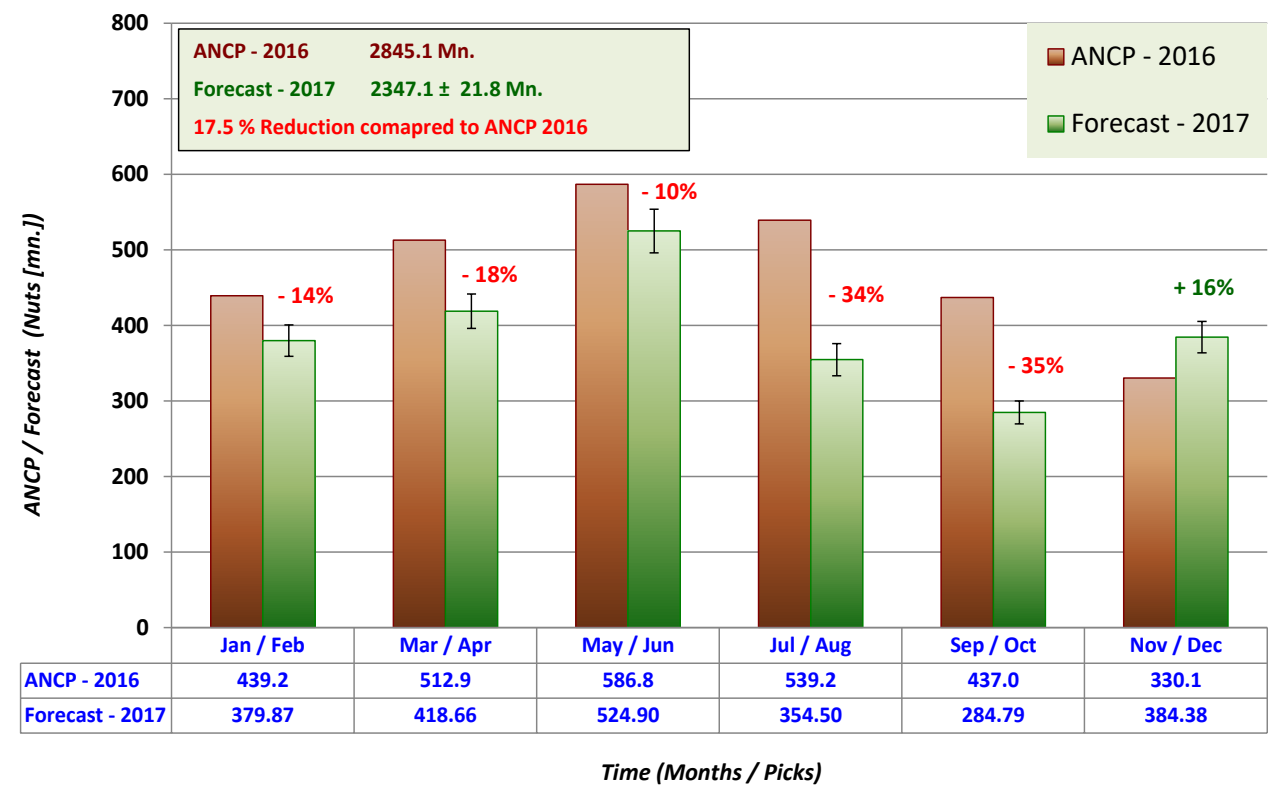

Figure 4: Comparison of coconut yield forecast for 2017 with annual national coconut production (ANCP) 2016

Source: Plant Physiology Division, CRI

\section{Methodology and Data}

An Equilibrium Displacement Model (EDM) of the Sri Lankan coconut industry developed by Pathiraja (2017) and reported in Pathiraja et al., (2017) was used to quantify the economic impact of possible nut shortage and de-husked nut importation. An EDM represents the economic framework of an industry by specifying its demand and supply relations and the price formation processes which link different market segments. It disaggregates the demand and supply relationships in a market both vertically and horizontally which allows assessment of the impact of external shocks in economic surplus terms among different stakeholders.

The conceptual diagram of the model is shown in Figure 5. This is based on the detailed mapping of the various sector value chains reported in (Pathiraja et al., 2015). Horizontally the industry is disaggregated into different products namely; fresh nuts, desiccated coconut, copra and other processed products. Vertically it is disaggregated into coconut production, processing, marketing and consumption. This is a partial equilibrium approach, so it is only the coconut industry that is described in this model.

Following previous EDM structures for Australian sheep and wool industries, Australian wine industry and Australian beef industry (Zhao, 1999; Zhao et al., 2003; Mounter et al., 2007; Mounter et al., 2008), each rectangle represents a production function. The arrows represent demand and supply relationships where an 
arrow head represents a product demand while the arrow shaft indicates the supply of a product. The ovals represent factor supplies and product demands where an exogenous shift would occur. The variables and parameters in the model are defined in Table 2.

The demand and supply relations of the nine industry sectors are indicated by forty two equations (Appendix 1). Three sets of data are required to solve the equations in the specified model.

First are elasticity values which define how producers and consumers respond to shifts in demand or supply curves. Empirically estimated parameters, theoretical considerations and judgments made by the authors with an expert view are some of the approaches used in acquiring the parameter values (Zhao, 1999; Mounter et al., 2005; Mounter et al., 2007). Product transformation and input substitution elasticities are not available in any previous studies. Therefore, the value of 0.1 is used as is common practice in other work (Zhao, 1999; Mounter et al., 2005; Henderson et al., 2006; Mounter et al., 2008). Other parameters were obtained from previous empirical estimates (Samarajeewa et al., 2002; Samarajeewa, 2002a, 2002b; Jayalath and Weerahewa, 2014). The selected parameter values are given in Table 3.

Second are prices and quantities which define the initial equilibrium conditions in the market - the starting point for any particular simulation. The base prices and quantities were estimated considering the five-year average of annual data (2009-2013). The data were obtained from the annual publications of the Coconut Development Authority and the Central Bank of Sri Lanka (Coconut Development Authority, 1970-2013; Central Bank of Sri Lanka, 2013). These data are shown in Table 4. Based on the discussion by Pathiraja et al., (2015), the average over these five years is considered to be representative of recent conditions.

Third are one or more non-zero "shifter" variables which define the initial displacement. In all cases, the various demand or supply shift scenarios are done on the basis that all other shift variables remain set to zero. That is, the shifters are examined one by one, in isolation. Typically in these sorts of analyses the shifts are specified as improvements or declines in productivity for supply side shifts and improvements or declines in consumer willingness to pay for demand side shifts.

Finally, when a disequilibrium is modelled, new equilibrium prices and quantities are estimated. These are then converted to measures of economic surplus for interpretation of the aggregate impacts of the disequilibrium. The various formulae used to calculate the economic surplus measures for each of the sectors are given in Appendix Table 1 (Alston et al., 1995). 


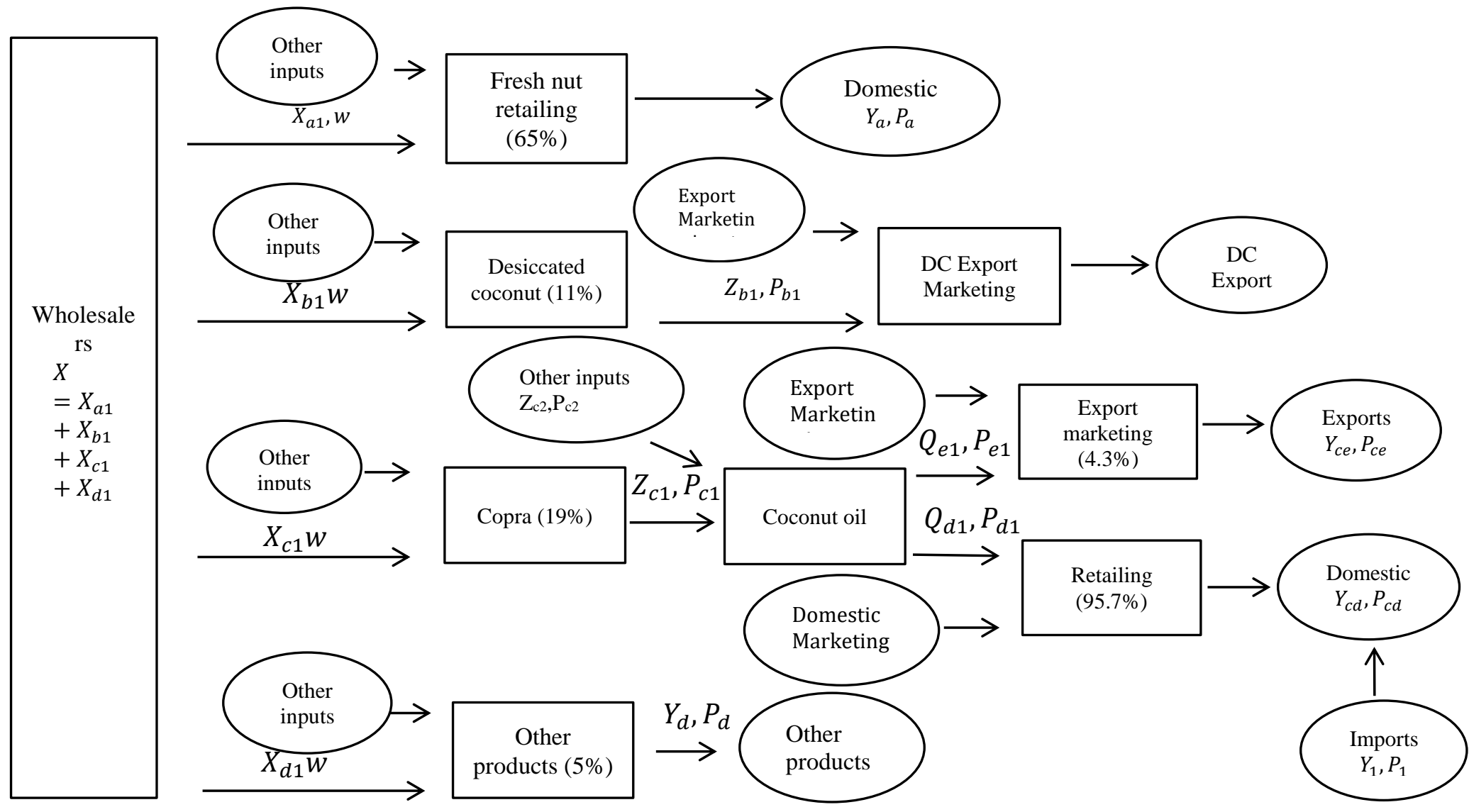

Figure 5: Structure of the model

Source: Pathiraja et al., 2017. 


\section{Table 2: Definition of variables and parameters in the model}

Endogenous variables

$X$

$X_{i 1}(\mathrm{i}=\mathrm{a}, \mathrm{b}, \mathrm{c}, \mathrm{d})$

$Z_{b 1}$

$Z_{c 1}$

$Q_{e 1}$

$Q_{d 1}$

$Y_{a}$

$Y_{b}$

$Y_{c e}$

$Y_{c d}$

$Y_{d}$

$X_{i 2}(\mathrm{i}=\mathrm{a}, \mathrm{b}, \mathrm{c}, \mathrm{d})$

$Z_{b 2}$

$Z_{c 2}$

$Q_{e 2}$

$Q_{d 2}$

$w$

$P_{b 1}$

$P_{c 1}$

$P_{e 1}$

$P_{d 1}$

$P_{a}$

$P_{b}$

$P_{c e}$

$P_{c d}$

$P_{d}$

$w_{a 2}$

$w_{b 2}$

$w_{c 2}$
Quantity of total coconut supply

Quantity of coconut supply for retailing(a), desiccated coconut(b), copra(c) and other processed products(d)

Quantity of desiccated coconut supply for export marketing

Quantity of copra supply for coconut oil production

Quantity of coconut oil supply for export marketing

Quantity of coconut oil supply for domestic retail marketing

Quantity of coconut demanded by domestic consumers

Quantity of export desiccated coconut demand

Quantity of export coconut oil demand

Quantity of domestic consumer coconut oil demand

Quantity of other product export demand

Quantity of other input supply for each product

Quantity of desiccated coconut export marketing inputs supply

Quantity of other coconut oil processing inputs supply

Quantity of coconut oil export marketing inputs supply

Quantity of coconut oil domestic marketing input supply

Supply price of coconuts

Price of desiccated coconut supplied for export marketing

Price of copra supplied for coconut oil processing

Price of coconut oil supplied for export marketing

Price of coconut oil supplied for domestic marketing

Price of domestic retail coconuts

Price of export desiccated coconut

Price of export coconut oil

Price of domestic retail coconut oil

Price of other export products

Price of other coconut retailing input supply

Price of other desiccated coconut processing input supply

Price of other copra processing input supply 
Table 2 contd...: Definition of variables and parameters in the model

Endogenous variables

$w_{d 2} \quad$ Price of other inputs supply for other export products processing

$P_{b 2} \quad$ Price of desiccated coconut export marketing inputs supply

$P_{c 2} \quad$ Price of other coconut oil processing inputs supply

$P_{e 2} \quad$ Price of coconut oil export marketing inputs supply

$P_{d 2} \quad$ Price of coconut oil domestic marketing input supply

$Z_{c} \quad$ Aggregated input index of coconut oil processing

$Q \quad$ Aggregated output index of coconut oil processing

Exogenous variables

$T_{x} \quad$ Supply shifters

$t_{x} \quad$ Amount of shift $T_{x}$ as a percentage of supply price

$N_{x} \quad$ Demand shifters

$n_{x} \quad$ Amount of $N_{x}$ as a percentage of demand price

Parameters

$\varepsilon_{x, w} \quad$ Supply elasticity of variable ' $\mathrm{x}$ ' with respect to change in price ' $w$ '

$\rho_{X_{a 1}}, \rho_{X_{b 1},} \rho_{X_{c 1},} \rho_{X}$ Quantity shares of $X_{a 1}, X_{b 1}, X_{c 1}, X_{d 1}$

$k_{x} \quad$ Cost share of input ' $\mathrm{X}$ '

$\gamma_{Y_{i}} \quad$ Revenue shares of output

$\sigma_{\left(X_{i}, X_{j}\right)} \quad$ Allen's elasticity of input substitution between input ' $X_{i}$ ' and input ' $X_{j}$ '

$\tau_{Y_{i}, Y_{j}} \quad$ Allen's elasticity of product transformation between outputs $Y_{i}$ and $Y_{j}$

$\eta_{(Y, P)} \quad$ Demand elasticity of variable ' $\mathrm{Y}$ ' with respect to change in price ' $\mathrm{P}$ '

$\bar{\varepsilon}_{x, w} \quad$ Constant-input output supply elasticity of output ' $\mathrm{X}$ ', with respect to change in input price ' $\mathrm{w}$.

$\bar{\eta}_{(Y, P)} \quad$ Constant-output input demand elasticity of input ' $\mathrm{X}$ ' with respect to change in input price ' $\mathrm{p}$.

Source: Pathiraja et al., 2017; Note: Different letters are used as subscripts to differentiate the products and markets those go for. 


\begin{tabular}{|c|c|c|}
\hline Parameter & Value & Source \\
\hline $\begin{array}{l}\text { Supply elasticity of } \\
\text { fresh nuts }\end{array}$ & $\varepsilon_{x, w}=0.195$ & $\begin{array}{l}\text { (Samarajeewa et al., } \\
\text { 2002; Samarajeewa, } \\
\text { 2002b) }\end{array}$ \\
\hline $\begin{array}{l}\text { Other factor supply } \\
\text { elasticities }\end{array}$ & $\begin{array}{l}\varepsilon_{x_{a 2}, w_{a 2}}=2, \varepsilon_{x_{b 2}, w_{b 2}}=2 \\
\varepsilon_{x_{c 2}, w_{c 2}}=2, \varepsilon_{x_{d 2}, w_{d 2}}=2 \\
\varepsilon_{Z_{b 2}, P_{b 2}}=2, \varepsilon_{Z_{c 2}, P_{c 2}}=2 \\
\varepsilon_{Q_{e 2}, P_{e 2}}=2, \varepsilon_{Q_{d 2}, P_{d 2}}=2\end{array}$ & $\begin{array}{l}\text { Based on assumptions } \\
\text { (Zhao et al., 2000; Zhao } \\
\text { et al., 2003; Henderson } \text { et } \\
\text { al., 2006) }\end{array}$ \\
\hline $\begin{array}{l}\text { Input substitution } \\
\text { elasticities (Allen- } \\
\text { Uzawa) }\end{array}$ & $\begin{array}{c}\sigma_{\left(X_{a 1}, X_{a 2}\right)}=0.1, \sigma_{\left(Z_{b 1}, Z_{b 2}\right)} \\
=0.1 \\
\sigma_{\left(X_{d 1}, X_{d 2}\right)}=0.1, \sigma_{\left(X_{c 1}, X_{c 2}\right)} \\
=0.1, \sigma_{\left(X_{b 1}, X_{b 2}\right)}=0.1 \\
\sigma_{\left(Z_{c 1}, Z_{c 2}\right)} \\
=0.1, \sigma_{\left(Q_{d 1}, Q_{d 2}\right)} \\
=0.1, \sigma_{\left(Q_{e 1}, Q_{e 2}\right)}=0.1\end{array}$ & $\begin{array}{l}\text { Not available in any } \\
\text { previous studies. } \\
\text { Common practice in other } \\
\text { work is to use } 0.1 \text { (Zhao, } \\
\text { 1999; Mounter et al., } \\
\text { 2005; Henderson } \text { et al., } \\
\text { 2006; Mounter } \text { et al., } \\
\text { 2008) }\end{array}$ \\
\hline $\begin{array}{l}\text { Product } \\
\text { transformation } \\
\text { elasticities }\end{array}$ & $\tau_{Q_{e 1}, Q_{d 1}}=0.1$ & $\begin{array}{l}\text { Common practice in other } \\
\text { work is to use } 0.1\end{array}$ \\
\hline $\begin{array}{l}\text { Domestic fresh } \\
\text { coconut retail demand } \\
\text { elasticity }\end{array}$ & $\eta_{\left(Y_{a}, P_{a}\right)}=-0.11$ & (Samarajeewa, 2002a) \\
\hline $\begin{array}{l}\text { Desiccated coconut } \\
\text { export demand } \\
\text { elasticity }\end{array}$ & $\eta_{\left(Y_{b}, P_{b}\right)}=-4.00$ & $\begin{array}{l}\text { Based on assumptions } \\
\text { (Samarajeewa, 2002b) } \\
\text { (Henderson et al., 2006). }\end{array}$ \\
\hline $\begin{array}{l}\text { Coconut oil export } \\
\text { demand elasticity }\end{array}$ & $\eta_{\left(Y_{c e}, P_{c e}\right)}=-2.00$ & Based on assumptions \\
\hline $\begin{array}{l}\text { Coconut oil retail } \\
\text { demand elasticity }\end{array}$ & $\eta_{\left(Y_{c d}, P_{c d}\right)}=-0.479$ & (Samarajeewa, 2002a) \\
\hline $\begin{array}{l}\text { Other products export } \\
\text { demand elasticity }\end{array}$ & $\eta_{\left(Y_{d}, P_{d}\right)}=-5.00$ & Based on assumptions \\
\hline
\end{tabular}

Source: Pathiraja et al., 2017 
Table 4: Base equilibrium prices, quantities and cost and revenue shares (average of 2009-2013)

\begin{tabular}{|c|c|c|c|}
\hline \multirow{2}{*}{$\begin{array}{l}\text { Market } \\
\text { Wholesalers }\end{array}$} & \multicolumn{2}{|c|}{$\begin{array}{l}\text { Quantity (million coconuts) and price } \\
\text { (LKR million) }\end{array}$} & \multirow[t]{2}{*}{$\begin{array}{l}\text { Cost, revenue and } \\
\text { quantity shares }\end{array}$} \\
\hline & $X=2,668$ & $w=27.10$ & \\
\hline & $T V=72,301$ & & \\
\hline \multirow[t]{4}{*}{ Coconut retailing } & $X_{a 1}=1,744.36$ & $w=27.10$ & $k_{X_{a 1}}=0.69$ \\
\hline & $T V_{X_{a 1}}=47,271$ & & $k_{X_{a 2}}=0.31$ \\
\hline & $Y_{a}=1,744$ & $P_{a}=39.53$ & $\rho_{X_{a 1}}=0.65$ \\
\hline & $T V_{Y_{a}}=68,947$ & & \\
\hline \multirow[t]{5}{*}{$\begin{array}{l}\text { Desiccated coconut } \\
\text { processing and } \\
\text { export marketing }\end{array}$} & $\begin{array}{l}X_{b 1}=286.49 \\
T V_{X_{b 1}}=7,764\end{array}$ & $w=27.10$ & $\begin{array}{l}k_{X_{b 1}}=0.95 \\
k_{X_{b 2}}=0.05\end{array}$ \\
\hline & $Z_{b 1}=286.49$ & $P_{b 1}=28.54$ & $k_{Z_{b 1}}=0.89$ \\
\hline & $T V_{Z_{b 1}}=8,176$ & & $k_{Z_{b 2}}=0.11$ \\
\hline & $Y_{b}=286.49$ & $P_{b}=32.23$ & \\
\hline & $T V_{Y_{b}}=9,232$ & & $\rho_{X_{b 1}}=0.11$ \\
\hline Copra processing & $X_{c 1}=502.35$ & $w=27.10$ & $k_{X_{c 1}}=0.99$ \\
\hline \multirow{10}{*}{$\begin{array}{l}\text { Oil processing and } \\
\text { marketing }\end{array}$} & $T V_{X_{c 1}}=13,613$ & & $k_{X_{c 2}}=0.01$ \\
\hline & $Z_{c 1}=502.35$ & $P_{c 1}=27.50$ & $k_{Z_{c 1}}=0.94$ \\
\hline & $T V_{Z_{c 1}}=13,815$ & & $k_{Z_{c 2}}=0.06$ \\
\hline & $Q_{e 1}=21.54$ & $P_{e 1}=29.15$ & $\gamma_{Q_{e 1}}=0.04$ \\
\hline & $Q_{d 1}=480.81$ & $P_{d 1}=29.15$ & $\gamma_{Q_{d 1}}=0.96$ \\
\hline & $Y_{c e}=21.54$ & $P_{c e}=55.90$ & $k_{Q_{e 1}}=0.52$ \\
\hline & $T V_{Y_{c e}}=1,204$ & & $k_{Q_{e 2}}=0.48$ \\
\hline & $Y_{c d}=480.81$ & $P_{c d}=34.53$ & $k_{Q_{d 1}}=0.84$ \\
\hline & $T V_{Y_{c d}}=16,604$ & & $k_{Q_{d 2}}=0.16$ \\
\hline & & & $\rho_{X_{c 1}}=0.19$ \\
\hline \multirow[t]{4}{*}{ Other products } & $X_{d 1}=134.39$ & $w=27.10$ & $k_{X_{d 1}}=0.57$ \\
\hline & $T V_{X_{d 1}}=3,653$ & & $k_{X_{d 2}}=0.43$ \\
\hline & $Y_{d}=134.79$ & $P_{d}=47.52$ & \\
\hline & $T V_{Y_{d}}=6,405$ & & $\rho_{X_{d 1}}=0.05$ \\
\hline
\end{tabular}

Source: Pathiraja et al., 2017 


\section{Results}

\section{Possible Economic Impact of a Yield Drop}

Fresh coconut supply and demand are both highly inelastic in nature, as shown in Table 3. Therefore, the industry is sensitive to even small changes in production. Such changes may be due to longer term declines in productivity, or to shorter term yield shocks due to adverse climatic events. When production declines, this is equivalent to an increase in the average variable cost of production in that sector. This is modelled as an upward supply shift of fresh coconut.

Table 5 shows possible impact distribution patterns among industry stakeholders from different levels of supply declines, from that calibrated for an equilibrium year. An equilibrium year represents the average situation of recent five years. According to the table, one per cent drop in yield causes a loss to the industry equivalent to 723 LKR million. This loss is distributed among all the stakeholders. The major share of the loss, 66 per cent, goes to "wholesalers" (growers, collectors and distributors of fresh nuts come under this category) followed by local consumers (28 per cent). The local consumers are mainly the fresh nut consumers ( 22 per cent loss) and coconut oil consumers (6 per cent loss). Nearly 4 per cent of the loss is distributed among export consumers among which desiccated coconut consumers are the most affected. Greater levels of yield decline result in proportionally greater industry losses, but the distribution of those losses among industry participants is unchanged.

Table 5: Possible pattern of economic surplus changes (in LKR million) and percentage shares of total surplus changes to various industry groups under different coconut productivity decline scenarios

\begin{tabular}{|c|c|c|c|c|c|c|}
\hline \multirow[t]{2}{*}{ Industry group } & \multicolumn{2}{|c|}{$1 \%$ supply drop } & \multicolumn{2}{|c|}{$2 \%$ supply drop } & \multicolumn{2}{|c|}{$5 \%$ supply drop } \\
\hline & LKR million & $\%$ & LKR million & $\%$ & LKR million & $\%$ \\
\hline $\begin{array}{l}\text { Fresh nut } \\
\text { wholesalers }\end{array}$ & -477.54 & 66.09 & -954.46 & 66.09 & -2381.54 & 66.08 \\
\hline $\begin{array}{l}\text { Fresh nut } \\
\text { retailers }\end{array}$ & -0.24 & 0.03 & -0.48 & 0.03 & -1.18 & 0.03 \\
\hline $\begin{array}{l}\text { Desiccated } \\
\text { coconut } \\
\text { processors }\end{array}$ & -0.93 & 0.13 & -1.85 & 0.13 & -4.60 & 0.13 \\
\hline $\begin{array}{l}\text { Copra other } \\
\text { input suppliers }\end{array}$ & -0.10 & 0.01 & -0.19 & 0.01 & -0.48 & 0.01 \\
\hline $\begin{array}{l}\text { Other export } \\
\text { products } \\
\text { processors }\end{array}$ & -6.19 & 0.86 & -12.35 & 0.85 & -30.66 & 0.85 \\
\hline $\begin{array}{l}\text { Desiccated } \\
\text { coconut } \\
\text { export } \\
\text { marketing }\end{array}$ & -2.38 & 0.33 & -4.74 & 0.33 & -11.77 & 0.33 \\
\hline
\end{tabular}


Table 5 contd...: Possible pattern of economic surplus changes (in LKR million) and percentage shares of total surplus changes to various industry groups under different coconut productivity decline scenarios

\begin{tabular}{|c|c|c|c|c|c|c|}
\hline \multirow{2}{*}{ Industry group } & \multicolumn{2}{|c|}{$1 \%$ supply drop } & \multicolumn{2}{|c|}{$2 \%$ supply drop } & \multicolumn{2}{|c|}{$5 \%$ supply drop } \\
\hline & LKR million & $\%$ & LKR million & $\%$ & LKR million & $\%$ \\
\hline $\begin{array}{l}\text { Coconut oil } \\
\text { other } \\
\text { processing }\end{array}$ & $\begin{array}{l}-0.39 \\
\end{array}$ & 0.05 & -0.78 & 0.05 & -1.95 & 0.05 \\
\hline $\begin{array}{l}\text { Coconut oil } \\
\text { export } \\
\text { marketing }\end{array}$ & -0.27 & 0.04 & -0.54 & 0.04 & -1.36 & 0.04 \\
\hline $\begin{array}{l}\text { Coconut oil } \\
\text { retailing }\end{array}$ & -1.23 & 0.17 & -2.45 & 0.17 & -6.12 & 0.17 \\
\hline $\begin{array}{l}\text { Subtotal } \\
\text { producer } \\
\text { surplus }\end{array}$ & -489.26 & 67.71 & -977.85 & 67.71 & -2439.66 & 67.70 \\
\hline $\begin{array}{l}\text { Domestic } \\
\text { coconut } \\
\text { consumers }\end{array}$ & -160.03 & 22.15 & -320.02 & 22.16 & -799.75 & 22.19 \\
\hline $\begin{array}{l}\text { Export } \\
\text { desiccated } \\
\text { coconut } \\
\text { consumers }\end{array}$ & -22.96 & 3.18 & -45.80 & 3.17 & -113.64 & 3.15 \\
\hline $\begin{array}{l}\text { Domestic } \\
\text { coconut oil } \\
\text { consumers }\end{array}$ & -43.52 & 6.02 & -86.98 & 6.02 & -217.05 & 6.02 \\
\hline $\begin{array}{l}\text { Export } \\
\text { coconut oil } \\
\text { consumers }\end{array}$ & -0.63 & 0.09 & -1.26 & 0.09 & -3.14 & 0.09 \\
\hline $\begin{array}{l}\text { Export other } \\
\text { products } \\
\text { consumers }\end{array}$ & -6.17 & 0.85 & -12.31 & 0.85 & -30.55 & 0.85 \\
\hline $\begin{array}{l}\text { Subtotal } \\
\text { consumer } \\
\text { surplus }\end{array}$ & -233.31 & 32.29 & -466.37 & 32.29 & -1164.12 & 32.30 \\
\hline Total surplus & -722.56 & 100 & -1444.22 & 100 & -3603.79 & 100 \\
\hline
\end{tabular}

Source: Pathiraja et al., 2017

Processors also encounter a loss from a supply decline, but it is comparatively less at nearly 2 per cent of the total loss. However, apart from the monetary value of the loss, the processors have issues regarding loss of their buyers/consumers due to low supply and comparatively high prices after which consumers may shift. Further, they have to keep the labour force (employees). 


\section{Economic Viability of Operating Sub Sectors Using Imported Nuts}

The results shown above are for relatively small reductions in supply. When supply reductions are much larger, as suggested by the yield decline during 2017, the losses in rupee terms to all stakeholders will be much greater.

If imports were allowed, the assumption would be that these imported nuts, and the value added products (DC or other products) produced from these nuts, would be completely separate from Sri Lankan nuts and the value added products (DC or other products) produced from Sri Lankan nuts. If so, it can be further assumed that there is no feedback between the imported nut "sector" and the domestic market, thus a completely separate product flow with no direct effect on Sri Lankan prices. In model terminology, the input substitution elasticity between sources of nuts is zero, and the output transformation elasticity between both types of value added products is zero. The only economic impact would be a reduction in Average Variable Cost (AVC) of processors, which would vary with the quantity allowed to be imported. Table 6 shows the possibility of reducing the negative impact of industry stakeholders when the cost is reduced from a scenario of 28 per cent to 10 per cent which was simulated based on a price reduction of fresh nuts from 43 LKR to 32 LKR.

Reducing the costs of processing desiccated coconut through importation of nuts reduces the losses to the processors and exporters from 15.5 LKR million per year to about 5.5 LKR million per year. Consumers of desiccated coconut exports are also better off by around 45 LKR million.

Table 6: Economic surplus changes (in LKR million) and percentage shares of total surplus changes to various industry groups under two different Cost of Production (COP) scenarios to DC processors

\begin{tabular}{lrrrr}
\hline Industry stakeholder & \multicolumn{3}{c}{ 28\% increase in COP } & \multicolumn{1}{c}{ 10\% increase in COP } \\
\cline { 2 - 5 } & LKR million & \multicolumn{1}{c}{ LKR million } & \multicolumn{1}{c}{$\%$} \\
\hline Fresh nut wholesalers & -267.16 & -45.14 & -95.44 & -0.51 \\
Fresh nut retailers & 0.26 & 0.04 & 0.09 & 0.00 \\
Desiccated coconut processors & -8.21 & -1.39 & -2.97 & -0.02 \\
Copra other input suppliers & 0.10 & 0.02 & 0.04 & 0.00 \\
Other export products processors & 6.78 & 1.14 & 2.42 & 0.01 \\
Desiccated coconut export & -7.31 & -1.23 & -2.62 & -0.01 \\
marketing & & & & \\
Coconut oil other processing & 0.43 & 0.07 & 0.15 & 0.00 \\
Coconut oil export marketing & 0.30 & 0.05 & 0.11 & 0.00 \\
Coconut oil retailing & 1.34 & 0.23 & 0.48 & 0.00 \\
& & & & \\
Subtotal producer surplus & 291.89 & 49.31 & 104.32 & 0.56 \\
& & & & 0.00 \\
\hline
\end{tabular}


Table 6 contd...: Economic surplus changes (in LKR million) and percentage shares of total surplus changes to various industry groups under two different Cost of Production (COP) scenarios to DC processors

\begin{tabular}{lrrrr}
\hline Industry stakeholder & \multicolumn{3}{c}{ 28\% increase in COP } & \multicolumn{1}{c}{ 10\% increase in COP } \\
\cline { 2 - 5 } & LKR million & $\%$ & LKR million & $\%$ \\
\hline Domestic coconut consumers & 174.50 & 29.48 & 62.31 & 0.33 \\
Export desiccated coconut & -70.55 & -11.92 & -25.32 & -0.14 \\
consumers & & & & \\
Domestic coconut oil consumers & 47.50 & 8.03 & 16.96 & 0.09 \\
Export coconut oil consumers & 0.69 & 0.12 & 0.25 & 0.00 \\
Export other products consumers & 6.76 & 1.14 & 2.41 & 0.01 \\
& & & & \\
Subtotal consumer surplus & 300.00 & 50.69 & 81.92 & 0.44 \\
Total Surplus change & 591.89 & 100.00 & 186.24 & 1.00 \\
\hline
\end{tabular}

\section{Other Factors to be Considered in Importing De-husked Nuts, Coconut Kernel and Copra}

The above example shows the possibility of minimizing the economic loss to the industry stakeholders through nut importation. However, following questions need to be answered before implementing the importation which was an objective of this study.

\section{What are the Sub Sectors which Required Imported Nuts and Market for those Products?}

In the above aspect, the processors should have a clear view on whether Sri Lanka has its world market share especially for the country of origin. For example, it is considered that Sri Lankan DC (and other products) has its market share for the unique taste and colour. If the processors are importing to blend with Sri Lankan coconuts and re-export as a blended product, the world demand for the new product should be assessed. If the demand is for the quality standards, demand for the processed products from foreign material should be considered. Therefore, request from each processor has to be quantified.

\section{Sri Lankan Brand and Quality Certification}

This is an important consideration in exportation of coconut products from Sri Lanka. When exporting coconut products especially DC, VCO, milk and milk powder it is very important to indicate the country of origin of the product. If imported coconut is used for value addition, the origin of the coconut should be indicated when re-exporting. In addition, the quality of produced materials using imported coconut should be compared with that of originated from Sri Lanka. If copra or coconut kernel is imported, there should be a specific quality guidance that will ensure the receiving of high quality products to Sri Lanka. 


\section{Duties and Levies for Importing De-husked Coconut}

Table 7 indicates the duties listed in imported de-husked coconut and copra. According to the calculation, around 100 per cent tax should be paid to clear the coconut and copra from the harbour. As given in the table, if the price of $1 \mathrm{~kg}$ of dehusked coconut is $50 \mathrm{LKR}$ (FOB), the total cost will reach to the level of $101 \mathrm{LKR}$, which is above the local price. Then, it is not worthwhile to produce DC as COP of DC exceeds the international market value. World prices for copra and kernel should also be considered in importing those products.

Table 7: Duties and levies for de-husked coconut and copra

\begin{tabular}{|c|c|c|c|c|c|c|c|}
\hline $\begin{array}{l}\text { FOB } \\
\text { Price } \\
(\mathrm{LKR} \\
/ \mathrm{Kg})\end{array}$ & $\begin{array}{r}\text { General } \\
\text { Duty } \\
(30 \%)\end{array}$ & $\begin{array}{r}\text { VAT } \\
(15 \%)\end{array}$ & $\begin{array}{r}\text { PAL } \\
(7.5 \%)\end{array}$ & $\begin{array}{l}\text { NBT } \\
(2 \%)\end{array}$ & $\begin{array}{r}\text { CESS } \\
\text { (30\% or } \\
\text { LKR } \\
110 / \mathrm{kg} \text { ) }\end{array}$ & $\begin{array}{r}\text { Total } \\
\text { duties and } \\
\text { levies } \\
(\mathrm{LKR} / \mathrm{kg})\end{array}$ & $\begin{array}{r}\text { Price }+ \\
\text { duties } \\
(\mathrm{LKR} / \mathrm{kg})\end{array}$ \\
\hline 50 & 15.00 & 13.54 & 3.75 & 1.81 & 16.50 & 50.59 & 100.59 \\
\hline 30 & 9.00 & 8.12 & 2.25 & 1.08 & 9.90 & 30.36 & 60.36 \\
\hline
\end{tabular}

Source: Sri Lanka Customs National Imports Tariff Guide -2017

Temporary Importation for Export Processing (TIEP) Scheme allows manufacturers who manufacture goods for export or indirect export to import inputs without payment of fiscal levies. By relieving manufacturers cum exporters from domestic taxes, it is expected to enhance the competitiveness of export production and encourage expansion of production capacities and exports. The importation of inputs such as raw-materials, components, parts and packaging materials comes under TIEP-1.

If de-husked nuts, kernel or copra are imported under TIEP program and reexported while processing those under the Board of Investment (BOI) regulations that will have a minimal effect on the local industry. Therefore, processing should be confined to the BOI zone and re-export of total output should be ensured. If de-husked nuts, kernel or copra is imported under tax concessions aiming to satisfy the local demand or processed in local factories that would influence the local market coconut prices while reducing the demand for nuts. This may control the unreasonable increase of fresh nut price. However, a quantity restriction has to be imposed to protect the nut price plummeting to an unreasonable level. If de-husked nuts, kernel or copra are imported under normal tariff, the price of products will not be competitive in the local market or international market as around 100 per cent taxes are applied for these products. Therefore, concessions may be required for the processors to survive while controlling the fresh nut price at a reasonable level for the growers. 


\section{Whether the Government Allows the Producers to Release Products of Imported Coconuts to the Local Market?}

Importation should be allowed only to keep the processing factories working during this climatic disaster until the yield is recovered. If it is expected to release to the local market, normal tariff levels should be applied or adjusted to give a reasonable price for the domestic coconut growers. However, the feasibility of this aspect should be clarified with the existing quarantine regulations to minimize the risk of pest and diseases (Department of Agriculture, 1981; 1999).

\section{Pest and Disease Issues and Impact to Genetic Base of the Country}

Sri Lanka's coconut genetic base is very narrow with a very limited number of "indigenous" and "exotic" coconut varieties. Nearly 80 per cent of the coconutcultivated area in the country is extensively grown with Sri Lanka tall or the typical tall variety. Hence the genetic diversity is comparatively low leaving the coconut population more susceptible to any introduced new pests and diseases. Furthermore, this will have irreversible and serious repercussions, even leading to a total destruction of the coconut cultivation. Even though Sri Lanka is yet fortunate to be free from lethal diseases of coconut, in the past country has had bitter experiences from introduction of pests and diseases. Those circumstances include complete destruction of about 30,000 acres of coconut lands in the early 1970s by the introduced pest Promecotheca cumingi, severe crop losses due to the infestation of coconut mite (Aceria guerreronis) and cutting down of well above 280,000 palms due to Weligama Coconut Leaf Wilt Disease (WCLWD) caused by Phytoplasma. This situation of the existing coconut cultivation has pointed out the significance of considering the possible threats for pest and diseases. Therefore, an extensive analysis of the risk of introduction of pest and diseases to the country should be conducted.

\section{Policy Implications}

According to the context analysis of coconut production, the processors confront with a nut shortage to meet their demand. The simulated results of the EDM shows that, the processors possibly be benefitted from fresh nut imports during this drought period. Importation is considered only for the export processing industries and it has a potential to reduce the economic loss for these industries which provide a considerable foreign exchange and employment. It is expected that input and export substitution elasticity values to be zero to protect the local and export markets. Therefore, strategic labelling process is necessary to prevent export substitution and to protect the Sri Lankan identity.

Another factor to be considered is adhering to the quarantine regulations. Even though importation of coconut fills the gap required for industry use, while taking into consideration the high risk of potential introduction of new pest and diseases, importation of coconut is not an option unless it is in compliance with the 
quarantine regulations. Hence, institutional set up need to be strengthened beforehand and a stepwise procedure should be followed. Importation of intermediate processed products (kernel and copra) will be an alternative for further value added products processing in the absence of any provision for fresh nuts. However, strict guidelines should be followed in labelling export products and in sealing the local market.

\section{References}

Alston, J.M., G.W. Norton, and P.G. Pardey (1995). Science Under Scarcity: Principles and Practice for Agricultural Research Evaluation and Priority Setting: Cornell University Press for the International Service for National Agricultural Research (ISNAR).

Central Bank of Sri Lanka. (2013). Annual Report. Retrieved from Central Bank of Sri Lanka, Colombo, Sri Lanka.

Central Bank of Sri Lanka. (2016). Annual Report. Retrieved from Central Bank of Sri Lanka, Colombo, Sri Lanka.

Chambers, R.G. (1988). Applied Production Analysis: A Dual Approach: Cambridge University Press.

Coconut Development Authority. (1970-2013). Sri Lanka Coconut Statistics. Retrieved from Coconut Development Authority, Colombo, Sri Lanka. https://cda.gov.lk/web/index.php?lang=en\#

Coconut Development Authority. (2012). Sri Lanka Coconut Statistics. Retrieved from Coconut Development Authority, Colombo, Sri Lanka. https://cda.gov.lk/web/index.php?lang=en\#

Coconut Development Authority. (2016). Sri Lanka Coconut Statistics. Retrieved from Coconut Development Authority, Colombo, Sri Lanka. https://cda.gov.lk/web/index.php?lang=en\#

Coconut Development Authority. (2017). Sri Lanka Coconut Statistics. Retrieved from https://cda.gov.lk/web/index.php?lang=en\#

Department of Agriculture. (1981). Plant protection ordinance. Retrieved from https://www.doa.gov.lk/SCPPC/NPQS/index.php/en/downloads.

Department of Agriculture. (1999). Plant protection act. Retrieved from https://www.doa.gov.lk/SCPPC/NPQS/images/PDF/Plant-protectionact.pdf.

Department of Census and Statistics. (2016). Household Income and Expenditure Survey Retrieved from Department of Census and Statistics, Sri Lanka. 
FAO. (2013). Food Balance Sheets. Retrieved from http://www.fao.org/faostat/en/\#data/FBS.

Fernando, M.T.N., L.M. Zubair, T.S.G. Peiris, C.S. Ranasinghe, and J. Ratnasiri (2007). Economic Value of Climate Variability Impacts on Coconut Production in Sri Lanka. Retrieved from The AIACC Project Office, International START Secretariat, Washington, DC: MTN Fernando, LM Zubair, TSG Peiris-2007- academiccommons.columbia.edu.

Henderson, B.B., L.A. Henry and T.G. MacAulay (2006). Investment and Change in the Coconut Industry of North Sulawesi: An Equilibrium Displacement Analysis. Paper presented at the Australian Agricultural and Resource Economics Society,2006 Conference (50th) Sydney, Australia. http://purl.umn.edu/139789.

Jayalath, K.V.N.N. and J. Weerahewa, (2014). Tariff Endogeneity: Effects of Export Price of Desiccated Coconuts on Edible Oil Market in Sri Lanka. Tropical Agricultural Research, 25(4), 376-386.

Ministry of Plantation Industries. (2007). National Plantation Industry Policy (NPIP) Framework. Retrieved from Ministry of Plantation Industries, Colombo, Sri Lanka.

Mounter, S.W., G.R. Griffith, R.R. Piggott and J.D. Mullen (2005). The Payoff from Generic Advertising by the Australian Pig Industry: Further Results Relative to the Payoff from R\&D. Australasian Agribusiness Review, 13(102).

Mounter, S., G. Griffith, R. Piggott, E. Fleming, and X. Zhao (2007). An Equilibrium Displacement Model of the Australian Sheep and Wool Industries. Economic Research Report (38).

Mounter, S., G. Griffith, R. Piggott, E. Fleming and X. Zhao (2008). Potential Returns to the Australian Sheep and Wool Industries from Effective R\&D and Promotion Investments and their Sensitivities to Assumed Elasticity Values. Australasian Agribusiness Review, 16(1).

Pathiraja, P.M.E.K., G.R. Griffith, R.J. Farquharson and R. Faggian (2015). The Sri Lankan Coconut Industry: Current Status and Future Prospects in a Changing Climate. Australasian Agribusiness Perspectives, 23.

Pathiraja, P.M.E.K., G.R. Griffith, R.J. Farquharson, and R. Faggian (2017). Specifying and Testing an Equilibrium Displacement Model of the Coconut Market in Sri Lanka. Australasian Agribusiness Review, 25. 
Samarajeewa, S.R., J. Weerahewa and H.M. Gunatilake (2002). Tariff Policy Liberalisation in Edible Oil Market and Its Implications on the Coconut Producers in Sri Lanka. Tropical Agricultural Research, 14, 317-326.

Samarajeewa, S.R. (2002a). An Econometric Analysis of Consumer Demand for Coconuts in Sri Lanka. CORD, Coconut Research and Development Journal, XVIII(2), 24-28.

Samarajeewa, S.R. (2002b). The Economic Impact of Selected Government Interventions on the Coconut Sector of Sri Lanka. (MPhil Unpublished), University of Peradeniya, Sri Lanka.

Sri Lanka Customs. (2017). Customs Tariff Retrieved from Department of Customs, Colombo, Sri Lanka.

Zhao, X. (1999). The Economic Impacts of New Technologies and Promotions on the Australian Beef Industry. (Doctor of Philosophy), University of New England, Armidale, N.S.W. Retrieved from http://epublications.une.edu.au/1959.11/10827

Zhao, X., K. Anderson and G. Wittwer (2003). Who Gains from Australian Generic Wine Promotion and R\&D? Australian Journal of Agricultural and Resource Economics, 47(2), 181-209. doi:10.1111/1467-8489.00209

Zhao, X., J.D. Mullen, G.R. Griffith, W.E. Griffiths and R.R. Piggott (2000). An Equilibrium Displacement Model of the Australian Beef Industry. Retrieved from Orange.

\section{Appendix 1}

\section{Fresh Nut Retailing}

Supply of other inputs

1. $X_{a 2=} f\left(w_{a 2}, T_{2}\right)$

Output constrained input demand functions

2. $X_{a 1}=Y_{a} * c_{Y a, w}^{\prime}\left(w, w_{a 2}\right)$

3. $X_{a 2=} Y_{a} * c^{\prime}{ }_{Y_{a}, w_{a 2}}\left(w, w_{a 2}\right)$

Fresh nut retailing value equilibrium condition

4. $c_{Y a}\left(w, w_{a 2}\right)=r_{x_{a}}\left(P_{a}\right)$

Domestic retail demand for fresh nuts

5. $Y_{a}=f\left(P_{a}, N_{1}\right)$

Equation 3 is the other retail marketing input supply function. This includes transportation, handling and transaction costs which are non-specific to this sector. $T_{2}$ is a supply shifter representing the impacts of efficiency improvements. Equation 4 and 5 are the output constrained input demand functions of $X_{a 1}$ and $X_{a 2}$ derived using Shephard's Lemma (Chambers, 1988, p. 261). $c_{Y a, w}^{\prime}\left(w, w_{a 2}\right)$ and 
$c^{\prime}{ }_{Y_{a}, w_{a 2}}\left(w, w_{a 2}\right)$ are the partial derivatives of the unit cost function. Equation 6 is the market clearing condition specifying that the unit price of fresh nuts at retail equals the unit costs of production. Equation 7 is the retail demand function for fresh coconuts. $N_{1}$ is a demand shifter in the retail market.

\section{Desiccated Coconut (DC) Processing}

Supply of other DC processing inputs

6. $X_{b 2}=f\left(w_{b 2}, T_{3}\right)$

Output constrained input demand functions

7. $X_{b 1=} Z_{b 1} * c^{\prime} Z_{b 1}, w\left(w, w_{b 2}\right)$

8. $X_{b 2}=Z_{b 1} * c^{\prime} Z_{b 1}, w_{b 2}\left(w, w_{b 2}\right)$

Desiccated coconut processing equilibrium

9. $\quad c_{Z b 1}\left(w_{b 2, w}\right)=r_{X_{b}}\left(P_{b 1}\right)$ value equilibrium

Equation 8 is the supply function of other processing inputs to desiccated coconut processing. Own price of inputs is represented by $w_{b 2} . T_{3}$ is a supply shifter of other inputs. Equation 9 and 10 are output constrained input demand functions of inputs $X_{b 1}$ and $X_{b 2}$ derived using Shephard's Lemma. $c_{z_{b 1}, w}^{\prime}\left(w, w_{b 2}\right)$ and $c_{Z_{b 1}, w_{b 2}}^{\prime}\left(w, w_{b 2}\right)$ are the partial derivatives of unit cost function with respect to input prices. Equation 11 shows the value equilibrium where output price equals the unit cost of producing output.

\section{Desiccated Coconut Export Marketing}

10. $Z_{b 2}=f\left(P_{b 2}, T_{6}\right)$ Marketing input supply

Output constrained input demand of export marketing inputs

11. $Z_{b 1=} Y_{b} * c_{Y b, P b 1}^{\prime}\left(P_{b 1}, P_{b 2}\right)$

12. $Z_{b 2}=Y_{b} * c_{Y b, P b 2}^{\prime}\left(P_{b 1}, P_{b 2}\right)$

DC export marketing value equilibrium condition

13. $c_{Y b}\left(P_{b 1}, P_{b 2}\right)=r_{Z b}\left(P_{b}\right)$

Export demand for desiccated coconut

14. $Y_{b}=f\left(P_{b}, N_{2}\right)$

Equation 12 is the export marketing input supply function of desiccated coconut. $P_{b 2}$ is the own price of inputs. $T_{6}$ is a supply shifter. Reduced brokerage fees or transaction costs, low cost packaging and transport are some of the possible reasons for more efficient processing. Equation 13 and 14 are the output constrained input demand functions of $Z_{b 1}$ and $Z_{b 2}$. These were derived from unit cost functions applying Shephard's Lemma.

Equation 15 shows the market clearing condition for export marketing where the output price equals unit cost of producing the output. Equation 16 is the export demand function for desiccated coconut. $P_{b}$, is the free on board (FOB) price and $N_{2}$ is the outward demand shifter. 


\section{Copra Processing}

Supply of other copra processing inputs

15. $X_{c 2}=f\left(w_{c 2}, T_{4}\right)$

Output constrained input demand functions

16. $X_{c 1=} Z_{c 1} * c^{\prime}{ }_{Z_{c 1}, w}\left(w, w_{c 2}\right)$

17. $X_{c 2}=Z_{c 1} * c^{\prime}{ }_{Z_{c 1}, w_{c 2}}\left(w, w_{c 2}\right)$

Copra processing value equilibrium

18. $c_{Z c 1}\left(w, w_{c 2}\right)=r_{X c}\left(P_{c 1}\right)$

Equation 17 is the supply function of copra processing inputs. $w_{c 2}$ is the own price and $T_{4}$ is a supply shifter. Equations 18 and 19 show the output constrained input demand functions of $X_{c 1}$ and $X_{c 2}$ derived using Shephard's Lemma. Equation 20 shows the market clearing condition for copra processing where the output price equals the unit cost of output.

\section{Coconut Oil Processing}

Other input supply for coconut oil processing

19. $Z_{c 2=f}\left(P_{c 2}, t_{8}\right)$

Output constrained input demand functions

20. $Z_{c 1}=Q * c^{\prime}{ }_{Q, P_{c 1}}\left(P_{c 1}, P_{c 2}\right)$

21. $Z_{c 2}=Q * c_{Q, P_{c 2}}^{\prime}\left(P_{c 1}, P_{c 2}\right)$

Coconut oil quantity and value equilibria

22. $Z_{c}\left(Z_{c 1}, Z_{c 2}\right)=Q\left(Q_{e 1}, Q_{d 1}\right)$

23. $c_{Q}\left(P_{c 1}, P_{c 2}\right)=r_{Z c}\left(P_{e 1}, P_{d 1}\right)$

Input constrained output supply

24. $Q_{e 1}=Z_{c} * r_{Z c, P_{e 1}}^{\prime}\left(P_{e 1}, P_{d 1}\right)$ Exports

25. $Q_{d 1}=Z_{c} * r_{Z c, P_{d 1}}^{\prime}\left(P_{e 1}, P_{d 1}\right)$ Domestic

Equation 21 is the input supply function of coconut oil processing inputs. Equations 22 and 23 are the output constrained input demand functions derived using Shephard's Lemma. Equation 24 is the multi output product transformation function where the aggregated input equals aggregated output in quantity. Equation 25 sets the unit cost incurred per unit of aggregated output $(\mathrm{Q})$ equal to unit revenue $\left(r_{Z c}\right)$ earned per unit of aggregated input $\left(Z_{c}\right)$. Equations 26 and 27 show the input constrained output supply functions of $Q_{e 1}$ and $Q_{d 1}$. Those are derived from unit revenue functions applying the Samuelson-McFadden Lemma (Chambers, 1988, p. 264).

\section{Export Marketing of Coconut Oil}

Marketing input supply

26. $Q_{e 2}=f\left(P_{e 2}, T_{9}\right)$

Output constrained input demand

27. $Q_{e 1=} Y_{c e} * c_{Y_{c e, P}{ }_{e 1}}^{\prime}\left(P_{e 1}, P_{e 2}\right)$ Demand for coconut oil

28. $Q_{e 2}=Y_{c e} * c_{Y_{c e, P}{ }_{e 1}}^{\prime}\left(P_{e 1}, P_{e 2}\right) \quad$ Demand for other marketing inputs 
Value equilibrium for export marketing

29. $c_{Y c}\left(P_{e 2,}, P_{e 1}\right)=r_{Q e}\left(P_{c e}\right)$

Export demand for coconut oil

30. $Y_{c e}=f\left(P_{c e}, N_{3}\right)$

Equation 28 is the supply function for coconut oil export marketing inputs related to its own price $P_{e 2} . T_{9}$ is a supply shifter for efficiency gains in marketing strategies that reduce the cost. Equation 29 and 30 are the output constrained input demand functions of $Q_{e 1}$ and $Q_{e 2}$ derived using Shephard's Lemma. Equation 31 shows the market equilibrium where unit cost of producing output equals the unit revenue or the output price. Equation 32 is the export demand for coconut oil related to its own price $P_{c e} . N_{3}$ is a demand shifter.

\section{Domestic Retail Marketing of Coconut Oil}

Other marketing input supply

31. $Q_{d 2}=f\left(P_{d 2}, T_{10}\right)$

Output constrained input demand of coconut oil

32. $Q_{d 1}=Y_{c d} * C_{Y_{c d, P} P_{d 1}}\left(P_{d 1}, P_{d 2}\right)$

33. $Q_{d 2}=Y_{c d} * c_{Y_{c d, P_{d 2}}}\left(P_{d 1}, P_{d 2}\right)$

Value equilibrium

34. $c_{Y_{c d}}\left(P_{d 1}, P_{d 2}\right)=r_{Q d}\left(P_{c d}\right)$

Domestic retail demand for coconut oil

35. $Y_{c d}=f\left(P_{c d}, N_{4}\right)$

Equation 33 is the retail marketing input supply of coconut oil related to its own price $P_{d 2} . T_{10}$ is a supply shifter, which may change due to more efficient use of marketing inputs that reduce the marketing margin, for example lower the cost storage, handling and distribution. Equations 34 and 35 are the output constrained input demand functions of $Q_{d 1}$ and $Q_{d 2}$ derived from unit cost functions. Equation 36 shows the value equilibrium where unit revenue (unit price of output) equals unit cost of producing output. Equation 37 is the retail demand for coconut oil related to its own price $P_{c d}$ and $N_{4}$ is a demand shifter.

\section{Other Export Products}

Supply of other processing inputs

36. $X_{d 2=} f\left(w_{d 2}, T_{5}\right)$

Output constrained input demand functions

37. $X_{d 1}=Y_{d} * c^{\prime}{ }_{Y_{d}, w}\left(w, w_{d 2}\right)$

38. $X_{d 2}=Y_{d} * c^{\prime} Y_{d,}, w_{d 2}\left(w, w_{d 2}\right)$

Value equilibrium

39. $c_{Y d}^{\prime}\left(w, w_{d 2}\right)=r_{X d}^{\prime}\left(P_{d}\right)$

Export demand

40. $Y_{d}=f\left(P_{d}, N_{5}\right)$ 
Equation 38 is the supply function of other processing inputs used in other export products processing. $w_{d 2}$ is the own price of inputs and $T_{5}$ is a supply shifter that shifts the supply curve due to lower cost technologies in processing.

Equations 39 and 40 are the output constrained input demand functions of $X_{d 1}$ and $X_{d 2}$ derived applying Shephard's Lemma to the unit cost functions. Equation 41 is the market clearing condition for other products that equates the unit cost of producing output to unit revenue earned. Equation 42 is the export demand for other products related to its own price $P_{d}$. and $N_{5}$ is a demand shifter.

Table 1: Formulae to calculate economic surplus

\begin{tabular}{ll}
\hline Coconut suppliers (Wholesale) & $\Delta P S_{X}=w X\left(E w-t_{1}\right)(1+0.5 E X)$ \\
\hline Retailing other input suppliers & $\Delta P S_{X_{a 2}}=w_{a 2} X_{a 2}\left(E w_{a 2}-t_{2}\right)\left(1+0.5 E X_{a 2}\right)$ \\
\hline $\begin{array}{l}\text { Desiccated coconut other input } \\
\text { suppliers }\end{array}$ & $\Delta P S_{X_{b 2}}=w_{b 2} X_{b 2}\left(E w_{b 2}-t_{3}\right)\left(1+0.5 E X_{b 2}\right)$ \\
\hline $\begin{array}{l}\text { Desiccated coconut export } \\
\text { marketing input suppliers }\end{array}$ & $\Delta P S_{Z_{b 2}}=P_{b 2} Z_{b 2}\left(E P_{b 2}-t_{6}\right)\left(1+0.5 E Z_{b 2}\right)$ \\
\hline Copra other input suppliers & $\Delta P S_{X_{c 2}}=w_{c 2} X_{c 2}\left(E w_{c 2}-t_{4}\right)\left(1+0.5 E X_{c 2}\right)$ \\
\hline $\begin{array}{l}\text { Coconut oil other processing } \\
\text { input suppliers }\end{array}$ & $\Delta P S_{Z_{c 2}}=P_{c 2} Z_{c 2}\left(E P_{c 2}-t_{8}\right)\left(1+0.5 E Z_{c 2}\right)$ \\
\hline $\begin{array}{l}\text { Coconut oil export marketing } \\
\text { input suppliers }\end{array}$ & $\Delta P S_{Q_{e 2}}=P_{e 2} Q_{e 2}\left(E P_{e 2}-t_{9}\right)\left(1+0.5 E Q_{e 2}\right)$ \\
\hline $\begin{array}{l}\text { Coconut oil retailing other input } \\
\text { suppliers }\end{array}$ & $\Delta P S_{Q_{d 2}}=P_{d 2} Q_{d 2}\left(E P_{d 2}-t_{10}\right)\left(1+0.5 E Q_{d 2}\right)$ \\
\hline $\begin{array}{l}\text { Other export products processing } \\
\text { input suppliers }\end{array}$ & $\Delta P S_{X_{d 2}}=w_{d 2} X_{d 2}\left(E w_{d 2}-t_{5}\right)\left(1+0.5 E X_{d 2}\right)$ \\
\hline Domestic coconut consumers & \multicolumn{1}{c}{$\Delta C S_{Y_{a}}=P_{a} Y_{a}\left(n_{1}-E P_{a}\right)\left(1+0.5 E Y_{a}\right)$} \\
\hline $\begin{array}{l}\text { Export desiccated coconut } \\
\text { consumers }\end{array}$ & $\Delta C S_{Y_{b}}=P_{b} Y_{b}\left(n_{2}-E P_{b}\right)\left(1+0.5 E Y_{b}\right)$ \\
\hline Domestic coconut oil consumers & $\Delta C S_{Y_{c d}}=P_{c d} Y_{c d}\left(n_{4}-E P_{c d}\right)\left(1+0.5 E Y_{c d}\right)$ \\
\hline Export coconut oil consumers & $\Delta C S_{Y_{c e}}=P_{c e} Y_{c e}\left(n_{3}-E P_{c e}\right)\left(1+0.5 E Y_{c e}\right)$ \\
\hline Export other products consumers & $\Delta C S_{Y_{d}}=P_{d} Y_{d}\left(n_{5}-E P_{d}\right)\left(1+0.5 E Y_{d}\right)$ \\
\hline Sum & $\Delta E S=\sum \Delta P S_{i}+\sum \Delta C S_{i}$ \\
\hline
\end{tabular}

